\title{
報 告経絡敏感者における耳針穴の経絡現象に ついて（弚の।）
}
北 出 利 勝
森川 和 宥
神野 英明
田中淳子
兵 頭 正 義

要旨 耳針療法は, 耳介上に反応点を探して, 刺針刺激を与之, 疾病 を治療する方法である。

経絡敏感者というべき著明な経絡現象を現わす患者の耳針穴に低周 波鍉針刺激を与えた。耳針穴の一部分の点において, 経絡現象が認め られた。

58歳(主婦)の左耳針穴(210穵)に対して, 通電装置により探索かつ刺 激した。その結果，耳針穴に鍉針刺激をして，針の響きがあったのは 約30\%であった。耳針穴の主治作用と針響部位が一致した耳針穴は， 「抜歯麻酔点」など $4.3 \%$ であった。耳針穴刺激により，つぎのような 訴えがあった。頭・眼が軽くなった。さわやかな気分になった。

\section{I はじめに}

耳針療法は，耳介上に反応点を探して，刺針刺 激を与之，疾病を治療する方法である。

1957年，P. Nogier（フランス)は耳針療法につ いて論文を報告した。その後，中国でも追試，実 践がくり返され，ハリ麻酔としても耳針穴を用い ている。また，一方で古典の文献を掘り起こし， 耳針穴の理論が集大成されたようである。

われわれは，経絡敏感者というべき著明な経絡 現象を現わす患者の耳針穴に低周波鍉針刺激を 与えた。そうしたところ，耳針穴の一部分ではあ るが，身体各部に経絡現象が認められたので報告

* Toshikatsu KITADE 大阪医科大学麻酔科ペインクリニ ック, 明治銊尒大学東洋医学教室

共同研究者 : Kazuhiro MoRIKAWA, Hideaki JINNO, Atsuko TANAKA, Masayoshi HyODO 大阪医科大学麻酔科 ペインクリニック

Key Words: 耳針分, 針響, 経絡敏感者, 経絡現象, 低 周波鍉針刺激法
する。

\section{II 調 查方法}

1) 対象患者

患者（被験者）は58歳の主婦で，神経質である。 とくに自分の疾病に対する関心が非常に強いこと が，心理的テスト（CMI テスト，矢田部ギルフォ 一ド性格検査, MD 検查法, MAS テスト) で伺う ことができる。大阪医大麻酔科ぺインクリニック で針炎治療を受けている。針治療に対する反応は 非常に敏感で, 治療効果も高かった（表1)。

2）耳針穴と刺激部位

耳針穴は，耳介表面，背面をあわせて 200 穴以 上存在する。耳針穴は子宮内で胎児がさかさまに おさまっているかのような（頭部を下にし，慜部 を上においた）状態で分布し，耳針穴とそれぞれ の部位を対応することができる。

刺激部位は, 左耳針穴で耳輪, 耳垂, 三角窩, 舟状窩など約17の部分に分けて刺激した。

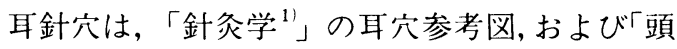
針と耳針 ${ }^{2)}$ の耳介穴位の分布図を参考にした。 


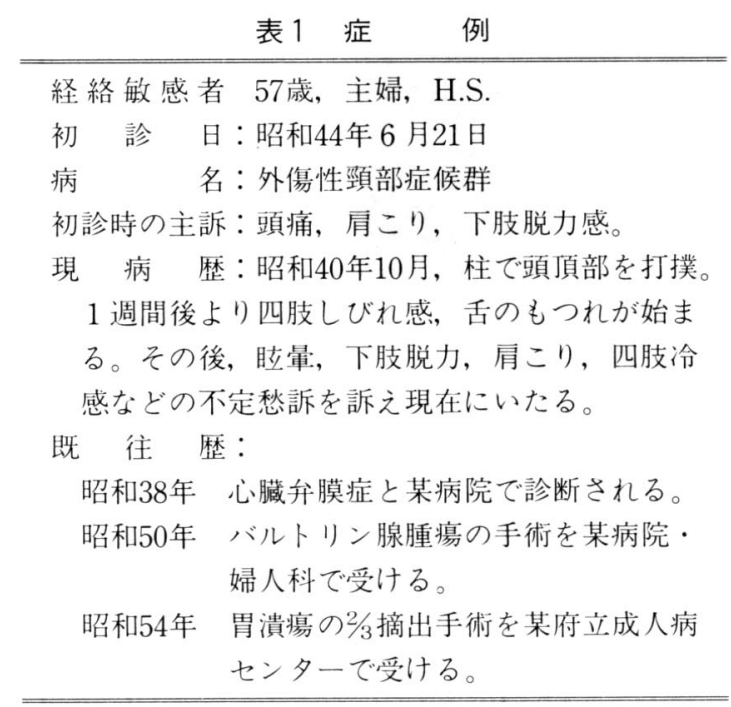

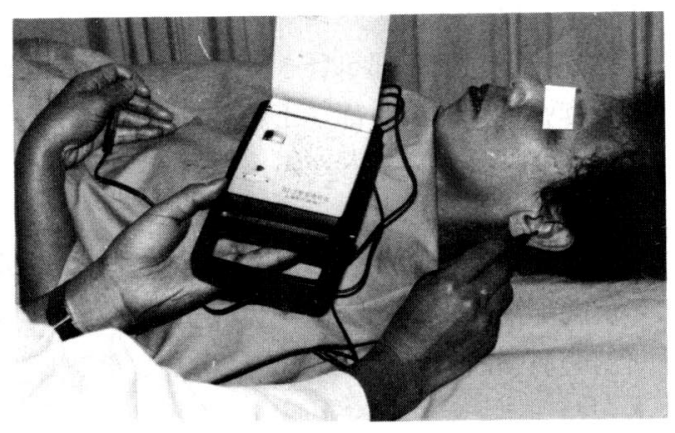

図 1 耳電針器DJ-3による耳針穴の探索と刺 激方法

\section{3）調查方法}

耳針穴は，上海医療器械店で製作された耳電針 器 $\mathrm{DJ}-3$ (耳電気探索器) で探索し, 同器で刺激 した。

刺激量は，被験者に電気的痛みを与之ない通電 量で，低周波鍉針刺激を行った（ sin wave， 0 $18 \mathrm{~V})$ 。刺激時間は，一つの耳針穴について 10 秒を
超えないものとした（図１）。

針響があった場合, 被験者が口頭および指で示 した響きを水性マーカーでペイント，あるいは頭 部や顔面部ではネットをかぶせて表わし, 写真撮 影を行った。

調查期間は, 昭和 57 年 7 月より昭和 58 年 5 月ま でで, 週 1 回の割合で約 1 時間行った(延30時間)。

\section{III 結 果}

1）耳針穴の主治作用と針響部位が一致した耳針 穴

$「$ 抜歯麻酔点 $2 」 「$ 気管支」「外耳」「扁桃体 $4 」$ $「 内 耳 」 「$ 尿道」「喘息」「輪 $4 」\ulcorner$ 中枢」であった。

(1) 抜歯麻酔点 2 (解剖部位: 耳垂, 主治作用: 抜歯時麻酔, 歯痛)

左中耳より左下顎部まで幅をもって響いた。

(2)気管支

中耳を奥へ入り，側頸部から咽頭部へ響いた。

(3)外耳

刺激部位から眼窩部へ響いた。また耳介前上 方に扇形で響いた。頭がうずくような感じがし た。

\section{(4)扁桃体 4}

側頸部に円形で響いた。

(5)内耳

外耳孔より内耳人入り，頭頂部入響いた。耳 の中が痒くなった。

(6)尿道の点（部位：耳輪, 作用：尿路感染症, 排尿困難)

刺激部位から, 前頸部を通り天突へ行き, 飛 んで, 膻中穴外方 1 寸より腹部腎経を下り, 臍 の下方から再び飛んで, 大腿内側部(血海), 下 腿内側 (脾経) を通り，母趾内側（隠白）まで の，長い範囲で線状に響いた。

(7)喘息

刺激部位から耳輪に響き，内耳に入り，下顎 の奥（咽頭部）より，喉頭へ響いた。

(8)輪 4

まず，耳介および耳介周囲に響き，中耳より 咽頭部に響いた。

(9)中枢

刺激すると, 強い頭痛を訴え, 耳介後方を線 


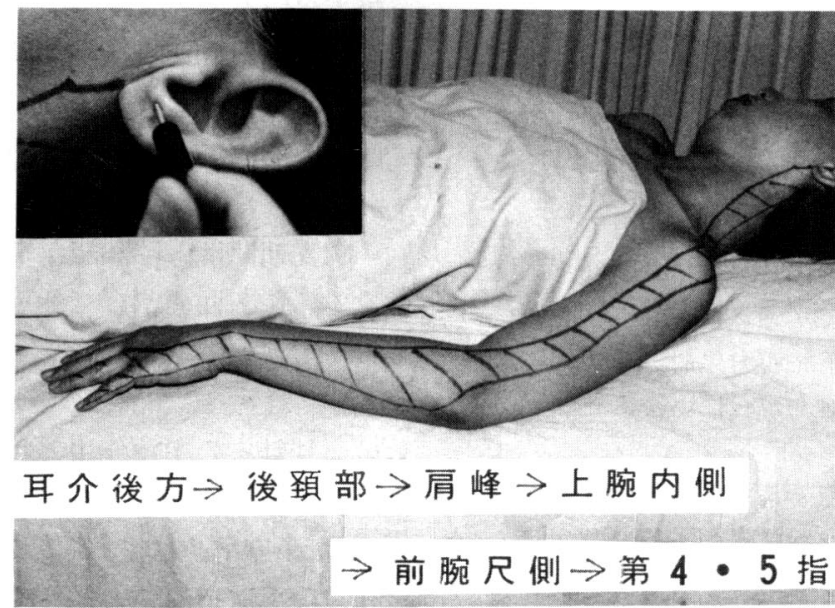

図2 下顎( 2 区)〈耳垂〉における経絡現象

状で頭の中までくい込んでくるような感じがし た。

2）頭部へ針響があった耳針穴

「輪 $1 」 「$ 輪 2 」腕」などであった。

(1)輪 1

刺激部より後頭部へ広い範囲で響いた。

(2)輪 2

耳介上方より線状で，頭頂部へ響いた。

(3)腕の点（部位：舟状窩, 作用 : 手根痛と機能 障害)

刺激部より，側頭部全体に響いた。

3）頸部へ針響があった耳針穴

「眼」「肝炎点」など11穴であった。

(1)眼

耳介の周りをまわって，中耳に入り咽頭部へ 響いた。

(2)肝炎点

刺激部位より，頭の中心に向かって 1 本の筋 になって感じる。

耳介下方より咽頭部へ, 細い線状で響いた。

4）頭部と钼部に針響があった耳針穴

「子宮」「外生殖器」など 6 穴であった。

(1)子宮

耳介前上方に響き，また後頸部から後頭部に
かけて響いた。重たい感じがする。

(2)外生殖器

外耳孔より咽頭部へ響き，耳介後方より後頭 部へ響いた。左側腹部，下肢外側が楽になった。

5）頸部と上腕部に針響があった耳針穴

(1)大腸

外耳孔から咽頭部を通り唉頭部へ響き，飛ん で肩関節前面より肘関節の少海まで響いた。反 対側の肩関節前面も響き(ジワーとした感じ)が あった。

(2)腎

大腸穴刺激とほぼ同じように，外耳孔から咽 頭部，喉頭部へ，飛んで肩関節前面より少海ま で響いた。

6）頸と上腕と前腕と手指に針響があった耳針穴 「下顎」「上領」であった。

(1)下顎の点（部位：耳垂 3 区, 作用：歯痛, 顎 関節症, 口内炎, 抜歯時の針麻酔)

耳介後方から後頸部, 肩先を通って前腕尺側 一行き，第 $4 ， 5$ 指へ带状に響いた（図 2 ）。

(2)上領 ( 3 区)

中耳より咽頭部に行き，肩関節部より上肢全 体に響いた。

頭が軽くなり，左半身・左眼が軽くなった。 


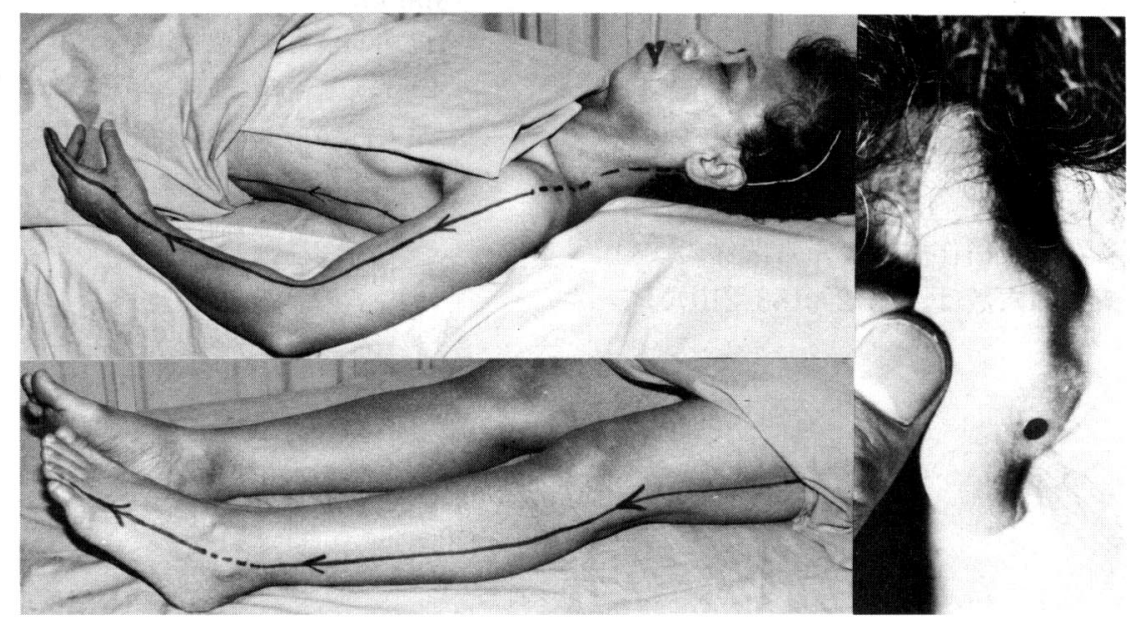

図3 上背〈耳背〉の点に刺激すると,つぎのように針響があった 頭頂部〔耳介上方 上背 $\rightarrow 耳$ 目部 $\rightarrow$ 肩峰 $\rightarrow$ 大腸経 $\rightarrow$ 商陽穴 $\rightarrow$ 腋窩 $\rightarrow$ 側腹 $\rightarrow$ 下肢外側 $\rightarrow$ 足の辤陰

7）ほぼ全身にわたり響いた耳針穴

「上背」穴であった。

○上背（部位：耳背部の耳甲介の隆起の下縁, 作用：腰部捻挫, 腰痛)

響きは,まず耳介上方より頭頂部へ行き, 耳介下 部より側頸部を通り，一方は肩関節より大腸経を 下方へ，示指末端まで行った。もう一方は肩関節 より飛んで，腋窩へ行き体側を通り，大腿外側・ 下腿外側を通り, 第 4 趾（篰㓌）まで響いた（図 3 )。

\section{IV 考察}

以上の結果から，次のようなことが考えられる。 一般のヒトにいくら耳針空に針刺激をしても，経 絡現象は起こらない。経絡敏感者においてこそ,こ のような針響が出現した。丸山，冨田の調査にお いても同様な針響が見られた。

同患者において，軀幹および四肢に経絡現象が 出現したのは, 耳針穴の約30\%である。また出現 しなかったのは約10\%である。

このことから，耳針穴の成立過程を推定するに，
たとえば10例のうち1例でも反応があれば，耳針 穴名を付けて acupuncture map を作成していっ たのであろう。したがって，全面的にそのまま， 耳針穴の治療効果を鵜吞みにできないといった方 がごく自然であろう。

本症例における針響時の被験者は，じわじわと しみる様な，重い感じとか，全身的にすずしい感 じなどを訴えた。

耳針穴の穴名通りに, 遠隔部の四肢または臓器 あたりに経絡現象があったことから耳針穴の治療 効果はある程度認めることができる。

わずか 1 例のリサーチであるので経絡敏感者に ついて，より多数例での克明な調查検討が必要で ある。またより客観的な方法により調查する必 要がある。

\section{V 結 語}

1）経絡敏感者（58歳，主婦）において, 針響 からみて耳針穴の存在意義と治療的意義（頭・眼 が軽くなった，さわやかな気分になった，下肢が 軽くなった）が一部分認められた。 
2) 耳介前面（160穴)および耳背（50穴）を調 查したが，わずかでも針響があったのは $29.5 \%$ (62/210穴)であった。

3）経穴名のところへ針響があった穴数は, 4.3 \% (9/210穴)であった。

4）耳針穴名及び主治作用となんら関係のない 部位に針響があった穴数は, $25.2 \%$ (53/210穴)で あった。

\section{引用文献}

1）井垣清明ほか訳：針炎学, 刊々堂 (1977).

2）杉充胤編訳：頭針と耳針，自然社（1975）.

( (569 大阪府高柣市大学町2-7

大阪医大麻酔科ペインクリニック，

₹629-03 京都府船井郡日吉町

明㳝鍼尒大学東洋医学教室)

\title{
The Meridian Phenomenon Induced by Ear Acupuncture in a Meridiansensitive Patient. (Part I )
}

\author{
Toshikatsu Kitade, Kazuhiro Morikawa, Hideaki Jinno, Atsuko Tanaka \\ and Masayoshi Hyodo, M. D. \\ Pain Clinic, Department of Anesthesiology, Osaka Medical College
}

\section{Summary}

In order to investigate the meridian phenomenon elicited by the stimulation on auricular acupuncture point, a patient, 58-year old, in whom marked meridian phenomena are observed on the body was selected as a subject.

The stimuli were ginen by means of a low frequency electrical stick method on the 210 auricular-points of the left ear.

The echo sensation to the remote district from the auriculo-points stimulated was observed in about $30 \%$ of the total points.

In $4.3 \%$, the site to which echo sensation reached corresponded to the response organ that is expresed in the name of point. A point named "anesthetic point for tooth extraction" was one of the representatives.

The comfortable feeling over head, eyes, and whole body was also observed when stimulation was given to these points. 